\title{
The Impact of the Digital Economy on Corporate Taxation From the Perspective of Supply Chain
}

\author{
Zhang Chen ${ }^{1, *}$, Gao Liting ${ }^{2, *}$ \\ ${ }^{1,2}$ Lanzhou University of Technology School of Economics and Management, Lanzhou, Gansu, China
}

\begin{abstract}
Supply chain is the unification of modern information flow, capital flow and logistics. Corporate tax management is an important part of corporate financial management, and its management results will have a direct impact on corporate development. In the current environment of rapid social and economic development, taxation management has penetrated into the entire supply chain of an enterprise, and has played its due value to the business development of the enterprise. Based on the perspective of the supply chain, this article studies the impact of the digital economy on corporate taxation, focusing on the analysis of the problems in corporate taxation management, and puts forward relevant suggestions based on the analysis results for reference.
\end{abstract}

\section{1 the impact of digital economy on corporate tax revenue}

In July 2020, General Secretary Xi Jinping proposed "to accelerate the formation of a new development pattern with the domestic cycle as the main body" at the entrepreneurs forum, which means striving to open up all links of production, distribution, circulation, and consumption in the supply chain. Dredge all blockages in the supply chain, and improve the flexibility of the supply chain that quickly responds to the market. ${ }^{[1]}$ In the context of digital economy, e-commerce, Internet finance, artificial intelligence, big data and other industries are developing rapidly, and the digital economy is growing and growing, contributing rapidly to the economy of all countries. In 2018, the proportion of the digital economy in the GDP of the United States, the United Kingdom and Germany has exceeded $60 \%$. Countries such as Japan, Ireland and France all account for more than $40 \%$ of GDP. In 2019, the global cross-border e-commerce market reached US $\$ 826$ billion, with a year-on-year growth of $22.4 \%$ (see Figure 1). With the continuous emergence of a large number of new business models and economic entities in the digital economy, corporate taxation is facing great challenges. The most typical business model of digital economy is that digital enterprises interact with consumers in other countries or countries remotely through the network or other digital media (such as electronic payment, APP, etc.) to provide them with digital products or services. The characteristics of high liquidity, high dependence on data and multi-level interactivity make the transaction process independent of "physical existence", which invalidates the definition of "permanent institution" in the traditional standard of tax jurisdiction division. As a result, a series of problems, such as base erosion, profit transfer, double taxation, etc. have been brought to various countries, which in turn have an impact on corporate taxation.

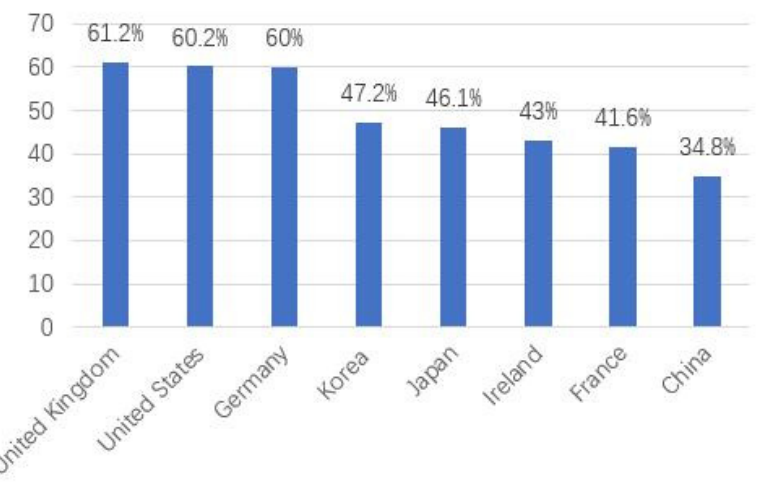

Figure 1. The share of GDP in the digital economy in major countries in 2018

\subsection{Formatting the title, authors and affiliations}

The differences in tax bases and tax rates among different countries are important reasons for cross-border tax avoidance, and the "Matthew Effect" of constant strength in the digital economy strengthens the motivation of enterprises to conduct tax avoidance arrangements. With the rapid development of large multinational digital companies, they have more ability and resources to choose low-tax countries around the world and lower their tax burden by setting up subsidiaries, offshore institutions, trusts and other means. Small and medium-sized enterprises lack corresponding strength, their business scope is mostly limited to a tax jurisdiction, unable to flexibly use the tax differences between countries, may face higher tax burden in competition. In addition, the core of value creation of digital economy is often intangible assets such as technology, information and

* Corresponding author: 1026378688@qq.com 
concession, which are characterized by high liquidity and high dependence on data ${ }^{[2]}$. The concealment of this economic model brings great convenience to the transfer pricing of intangible assets. The economic ownership and legal ownership of intangible assets in the digital economy are not completely bound. By means of transfer pricing, cost sharing agreement and other ways, the two ownership can be separated, which can easily realize the redistribution of value, make corporate profits flow between countries with different tax burdens, and realize the erosion of the tax base and profit transfer of enterprises. The convenience of transfer pricing for digital enterprises creates incentives for tax noncompliance, which greatly increases the tax risk.

\subsection{The space for corporate tax revenue will be expanded}

In the traditional tax system, the determination of a permanent institution is of great significance to whether a non-resident enterprise is liable to pay tax in its place of origin. In the context of the digital economy, cross-border e-commerce relies on "virtual presence" to complete a series of activities such as research, procurement and delivery, which greatly challenges the existing definition of a permanent organization. Therefore, according to the traditional tax jurisdiction system, the definition of permanent institutions cannot meet the needs of the source country for the tax collection and management of digital enterprises that have no physical existence. A large number of digital enterprises do not need to pay taxes in the source of income, so they are unable to tax crossborder income obtained through online payment and other means, damaging the tax interests of the source.

In addition, in the context of digital economy, in addition to the traditional definition of permanent organization, which makes the profit distribution of multinational enterprises unreasonable, there is another reason for the controversy of profit ownership. The principle of independent transaction, which is the profit distribution principle of traditional standing organization, has a difficult application problem. On the one hand, enterprises allocate single functions to different institutions around the world through cross-border transactions, which makes it difficult to judge the functions of various departments or institutions of enterprises. Multinational enterprises in income sources, on the other hand, the main existence form of the digital media (such as websites, server, etc.), in the process of value creation, the digital media is bearing the weight of the core functions of value creation, its execution and completion of trading, there is no mature market deals with traditional physical media is not comparable, It is impossible to find the profit rate or market rate of return of comparable transactions to determine the fair transaction price, so that there is a large space for tax avoidance among related enterprises.

\section{The response of the international community}

The Organization for Economic Cooperation and Development (OECD) will address the tax challenges of the digital economy as the first action plan of the Tax Base Erosion and Profits Shifting (BEPS) project, which has aroused wide resonance in countries around the world. In order to cope with the challenges of global digital economy to corporate tax compliance, countries have taken some unilateral measures one after another. International organizations represented by OECD have also actively launched multilateral international coordination mechanisms.

\section{1 strengthen international tax coordination and cooperation and reduce differences in tax systems}

The differences in tax systems stem from the differences in national conditions and involve a wide range of interests, which cannot be unified through a single international system of rules. Digital economy intensifies the tax risk and compliance burden caused by tax differences, so it is imperative to reduce tax risk through active political and economic consultation and international tax cooperation. The original intention of the EU is to establish a single market within the region and realize the barrier-free flow of resource elements among member states. Therefore, the EU's exploration of the unified tax system can provide an important reference for the formulation of international tax rules.

\section{2 improving the reservation pricing arrangement system and increase the certainty of intangible assets transfer pricing}

With the development of digital economy, the types of intangible assets become more and more complex, and the principle of independent transaction is facing more and more applicable difficulties. Thus the formula assignment method began to receive attention. The formula distribution method means that the transnational corporation distributs the total profit before tax between organizations according to the proportion of the sales revenue, price, assets and other indicators of the subsidiaries or branches. Its advantage is that intangible assets are "materialized" and the tax base is divided according to objective indicators such as asset size and sales revenue, which is in line with the reality that intangible assets create value in the cooperative operation of multinational enterprise groups, and is conducive to combating tax avoidance arrangements brought about by the transfer of ownership of intangible assets. In order to avoid problems such as difficulty, high cost and strong uncertainty of post-adjustment, reservation pricing arrangement with pre-adjustment has been rapidly promoted all over the world. According to the number of unilateral, bilateral or multilateral reservation pricing arrangements in the countries involved, the tax authorities of the countries involved and the MNEs sign an 
agreement on transfer pricing between related entities. The reservation pricing arrangement effectively coordinates the tax interests of various countries, helps to reduce the tax disputes between the two parties, and reduces the cost of tax collection and management and the risk of tax base erosion.

\section{3 promoting systematic system design and try to resolve disputes between the determination of permanent institutions and profit distribution}

In the digital economy tax challenges, standing body of judgement is closely linked with the profit distribution of controversy, its essence lies in the contradiction of the international tax jurisdiction, so for the solution of the two problems need to be systematic system, in the thinking of the international community by a new tax, the lowest tax rates or withholding income tax will be strongest tax benefits in fixed income source reference.

Digital services such as search and advertising are subject to a $2 \%$ digital services tax. The establishment of this kind of new tax category affirms the value created by "user participation" from the taxation practice, which is to confirm the tax jurisdiction based on the standard of "user participation" under the new business model. However, its implementation process also faces many challenges. ${ }^{[4]}$ The international community cannot reach a consensus on digital service tax in the short term, and there are still many uncertainties in the formulation and implementation of international tax rules. The tax governance of digital economy requires countries to actively fulfill their responsibilities and obligations for global governance.

\section{The proposal to reduce the tax risk of chinese enterprises from the perspective of supply chain}

With the rapid development of digital economy, in order to improve the tax compliance of taxpayers and reduce tax risks, China has also carried out active institutional exploration.In 2015, China set up the China (Hangzhou) Cross-border E-commerce Comprehensive Pilot Zone in Hangzhou, and introduced new measures to support the construction of the Science and Innovation Center of the Free Trade Zone in Shanghai. One of the pilot contents is to build a large database of cross-border e-commerce and build a multi-dimensional comprehensive index system of cross-border e-commerce. The implementation of index supervision and tax declaration monitoring across the whole industrial chain is conducive to better serving and promoting cross-border trade activities and improving the satisfaction of tax paying enterprises.

Comparing the measures to deal with the tax risks of the international digital economy and analyzing the results of national interest considerations and games are conducive to enhancing the understanding of the tax risks of enterprises under the digital economy and providing a starting point for the formulation of relevant tax policies and the implementation of regulatory measures in China. In the face of tax management challenges brought by digital economy, it is necessary to start from the macro system design level, draw on the beneficial experience of various countries, and formulate targeted strategies according to the characteristics of risks. ${ }^{[3]}$

\subsection{Tax optimization based on supply chain perspective}

Reasonable and efficient tax system and tax collection and management system can promote taxpayers' trust and recognition of tax, help to build a tax collection and payment relationship of mutual trust and reciprocity, ensure enterprises' cooperation and compliance from the system, improve the effect of tax administration, and safeguard the sovereign interests of the country. A careful revision standing body for standing body defining the problem escape clause, or reference to international practices, the introduction of new join point solutions, such as "significant economic existence" or minimum tax system design, to ensure tax compliance of non-resident enterprises in our country, but also avoid the abuse of administrative discretion to damage the interests of the taxpayers trust. Secondly, according to the characteristics of the intangible assets transfer pricing in the digital economy, actively studying mending the lack of laws and regulations, and by the tax administration law of the People's Republic of China amended as an opportunity to strengthen the related tax management terms, with strict administration punishment against digital enterprise through the intangible asset transfer pricing tax arbitrage.

\subsection{Talent training level based on the perspective of supply chain}

Digital talent is fundamental to meeting the challenges of the digital economy. At present, the tax system lacks a big data professional training and management mechanism, administrative personnel have uneven business ability, the structure is aging, and the utilization rate of big data analysis tools is low. Tax officials is highly dependent on traditional experience, interpretation of tax-related data is static access and shallow level stage, lack of internal motivation and external pressure mechanism, data management ability is weak, cannot achieve, trend prediction analysis of mathematical statistics and data logic depth excavation, effectively for the tax risk is more difficult to identify. Should make good use of the third party think tank, the recruitment or the introduction of professionals, forming a large data expert team, invited the professional teaching, training and selecting young cadres to the relevant colleges, for big data tax reserve talent strength, and according to the need to comply with tax cooperation mechanism of the construction, post personnel dynamic adjustment, gradually increase the data processing class type technical support personnel.

\subsection{The level of international cooperation based on the perspective of supply chain}

Strengthen the thinking of big data and realize the modernization of tax governance with the ability of "ruling number". First, we will improve the tax big data 
management system. At present, the Golden Tax Phase III system has realized the digitization of part of the business, but it is far from reaching the intelligent level. ${ }^{[5]}$ Therefore, it is necessary for the tax department to adopt the new generation of information technology and develop a tax big data management system with more complete functions. The second is to improve the information sharing mechanism and the systematic construction of cotax obligations. We will continue to explore the sharing boundaries and use methods of cross-department data resources, and establish a nationwide unified data sharing platform to facilitate the collection and repeated use of tax information and greatly reduce the cost of declaration compliance for enterprises. Third, a framework for tax compliance risk management should be formed. Through the construction of tax compliance risk management framework, the tax environment is digitized and tax compliance is instrumented, and the independent participation of taxpayers and tax risk are reduced.

\subsection{Level of International Cooperation based on the perspective of supply chain}

As a big digital economy country, China should pay close attention to the dynamics of the reshaping of international tax rules for digital economy, timely follow up the G20 tax reform work plan, and pay special attention to the study process of the "Double Pillar" plan of OECD. We should actively participate in the formulation of international tax rules with an open, independent and inclusive attitude, vigorously promote the reform of international tax under the background of economic digitalization, and ensure the fair and reasonable distribution of tax jurisdiction. We will actively seek bilateral or regional tax cooperation, continue to play a leading role in the United Nations Commission of Experts on International Taxation, resolutely safeguard tax sovereignty and effectively protect the legitimate rights and interests of Chinese enterprises. At the same time, it is recommended that the perfect digital economy information exchange mechanism of enterprises, to promote multinational enterprise tax information sharing, mastering the development trend of enterprises, in advance for the possibility of tax disputes, on the premise of strengthening the cooperation of the information, also should notice to protect taxpayers' privacy and business secrets, establish corresponding legal liability mechanism, Serve the "going out" enterprises and manage the "brought in" enterprises well, and improve the voluntary compliance degree of taxpayers in an all-round way.

\section{Conclusion}

The tax management of enterprises is very important in daily operation. Combining the theory of supply chain with the tax management of enterprises, that is, the tax management of enterprises under the background of digital economy from the perspective of supply chain is most in line with the development of current enterprises. This paper selects Chinese enterprises as the analysis object, finds out the problems in the taxation management of Chinese enterprises, and proposes optimization suggestions. This article draws on the tax system thinking of various countries, China should take active measures from tax system optimization, talent training, information construction and international cooperation to improve the tax compliance of enterprises.

\section{References}

1. Zhang Xueyun. (2021) Research on Enterprise Working Capital Management from the Perspective of Supply Chain.J, Chinese Business,03:109-110.

2. Shi Meilong. (2021) The Role and Development of Logistics Supply Chain Finance under the Background of Economic Double Cycle.J, Chinese Business, 10:1-3.

3. Zhang Bin. (2016) The Impact of the Digital Economy on Taxation: Challenges and Opportunities. J, International taxation, 6:30-32.

4. Chen Ming. (2018) Regional tax coordination in the context of "Belt and Road": EU enterprise income tax experience.J, Local financial research,12: 90-95.

5. Li Rui, Li Shuijun. (2020) Digital economy: How China's tax system responds.J, Tax research,03:91-98. 